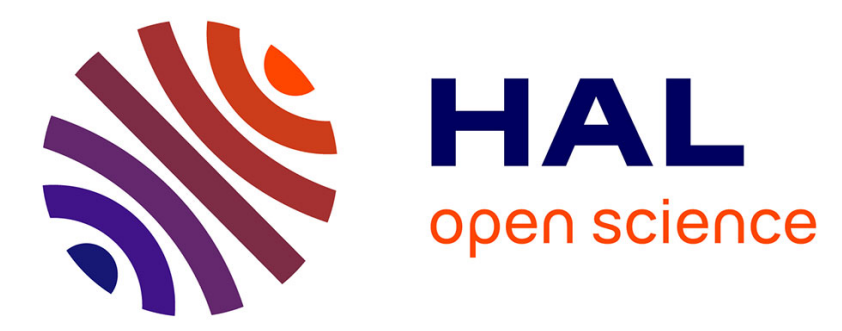

\title{
Moroccan Forestry Policies and Local Forestry Management in the High Atlas: A Cross Analysis of Forestry Administration and Local Institutions
}

Pierre-Marie Aubert, Maya Leroy, Laurent Auclair

\section{To cite this version:}

Pierre-Marie Aubert, Maya Leroy, Laurent Auclair. Moroccan Forestry Policies and Local Forestry Management in the High Atlas: A Cross Analysis of Forestry Administration and Local Institutions. Small-Scale Forestry, 2009, 8 (2), pp.175-191. 10.1007/s11842-009-9076-4 . hal-01466555

\author{
HAL Id: hal-01466555 \\ https://hal.science/hal-01466555
}

Submitted on 11 Dec 2019

HAL is a multi-disciplinary open access archive for the deposit and dissemination of scientific research documents, whether they are published or not. The documents may come from teaching and research institutions in France or abroad, or from public or private research centers.
L'archive ouverte pluridisciplinaire HAL, est destinée au dépôt et à la diffusion de documents scientifiques de niveau recherche, publiés ou non, émanant des établissements d'enseignement et de recherche français ou étrangers, des laboratoires publics ou privés. 


\title{
Moroccan Forestry Policies and Local Forestry Management in the High Atlas: A Cross Analysis of Forestry Administration and Local Institutions
}

\author{
Pierre-Marie Aubert $₫$ Maya Leroy $\&$ Laurent Auclair
}

\begin{abstract}
This paper examines how local forestry management has evolved in the Ait Bougmez Valley (Central High Atlas, Morocco) in the last three decades and how this evolution has affected forest ecosystem conditions. It focuses on the impact of the forestry administration on 'traditional forestry management' since its introduction in 1985, and of recent innovation in forestry policy. The relatively new Strategic Environmental Management Analysis (SEMA) framework is applied, rather than a more 'classical' new institutional framework. This approach allows for a more comprehensive understanding of both strategic interactions between various actors and ecological consequences of these interactions. An interesting empirical findings is that instead of a quite simple opposition between the forestry adminis- tration and local populations, negotiation opportunities exist that are taken by the actors. This leads to specific actor configurations and sometimes unexpected environmental outcomes, even if from a global point of view, forest stands have been seriously depleted over the last 40 years mainly due to exploitation by local population and the absence of economic alternative to forest exploitation. On the other hand, the implementation of a new policy tool in such a context has to be understood as an opportunity for new actors to take part in forest management rules definition.
\end{abstract}

Keywords New institutionalism Common property theory Strategic environmental management analysis Forestry policy Morocco

P.-M. Aubert (\&) M. Leroy

Environmental Management of Tropical Forests and Ecosystems' Research Unit,

AgroParisTech-ENGREF Montpellier, Agropolis, 648 rue Jean François Breton, BP 7355,

Montpellier cedex 4 34086, France

e-mail: pm.aubert@agroparistech.fr

P.-M. Aubert L. Auclair

French Research Institute for Development (IRD), Marseille, France 


\section{Introduction}

Over the last three decades, the role of local communities in natural resources conservation has been more and more widely recognized. Since the 1990, a large part of the scientific literature devoted to natural resource management in developing countries has thus focused on local communities' capacities to manage carefully their resources through specific institutions (Ostrom 1990; Baland and Plateau 1996; Agrawal 2001). It has been shown in several countries that the intervention of the state has led to a loss of legitimacy of these local institutions, which in turn has provoked severe degradation, particularly in the forest sector (Auclair 1998). To overcome this problem, recognition of local institutions and devolution of forest resources management and access rights to local communities has become an important issue (Behera and Engel 2006). Taking into account the fact that the forestry administration and local communities were already interacting together, authors such as Baland and Plateau (1996) have rather called for a co- management regime where they both have rights and responsabilities.

The Moroccan Forestry Administration, which is known to have had a centralised, hierarchical and coercive approach to forestry management over the years (Davis 2007), now claims to have adopted this idea. The policy for attaining it is defined in the National Forest Program ${ }^{1}$ (NFP), approved in 1999 (MCEF 1999). As a first implementation step, a ministerial decree on compensation of exclusion of grazing animals was issued in 1999. This decree is said to be a major tool towards the establishment of partnerships between the forestry administration and local populations (MCEF 2002). Such partnerships are supposed to result in better forest conservation and local population participation.

In the central High Atlas, forest depletion is a major problem for the forestry administration which has always considered its protection as a major objective. These mountain forests are also intensively exploited by local populations as an important part of their livelihood, and forest exploitation is submitted to several rules designed by the populations themselves. One of these rules, called agdal, has been studied by pastoralists and experts of 'common property'; it aims to preserve forest and pasture by preventing their exploitation for a specified period (Lecestre- Rollier 1992; Auclair 1996). The practices, implemented by established local institutions and structures, are supported by empirical ecological knowledge and have ecological impacts (Hammi et al. 2007).

This paper focuses on the case of the Ait Bougmez Valley, in the central High Atlas. Its objective is to shed light on the historical evolution of interaction patterns between the forestry administration and the local population, its ecological consequences and how the new policy tool (the decree on compensation for exclusion of grazing animals) is likely to provoke any change. The analysis utilizes the Strategic Environmental Management Assessment framework (described by

11 A National Forest Program has been defined as 'generic expression for a wide range of approaches to the process of planning, programming and implementing forest activities in countries' (CSD-IPF 1996, para. 25, in Schanz 2002, p. 269) 
Mermet et al. 2005). Use of this theoretical framework to analyse the evolution of local forest management brings into debate the 'common property resources paradigm', which has become the standard model for analysing natural resources management over the last decade, especially in developing countries (Johnson 2004).

The next section discusses the interest of the Strategic Environmental Management Assessment framework compared to what can be called the "common property resources paradigm, (e.g. Ostrom 1990) and presents the research method. The case study area of the Ait Bougmez Valley is then described. Next, local forestry management before the forestry administration arrival in the valley, and the impact of this arrival on local forestry management, are analysed. Changes in forest policy and the forestry administration's ability to develop a partnership with the emergent local associations are questioned. Concluding comments follow.

\section{Theoretical Framework and Research Method}

Rejecting and in many case disproving Hardin's famous parable (1968), 'commons scholars' have documented over the last 20 years literally thousands of cases in which people have been able to create, maintain or re-organize common property. As noted by Johnson (2004), it would be no exaggeration to say that nowadays, this theoretical framework has come to largely dominate the scientific literature about natural resources management, especially in developing countries. At the centre of this school of thought is the idea that institutional arrangements - and particularly property rights - influence to a great extent the way people use and manage natural resources, and that particular institutional configurations can positively influence resource conservation. A set of institutional 'design principles' has been derived from the numerous empirical studies mentioned above; the more an institutional arrangement is in accordance with these principles, the more likely it is to result in sustainable management of natural resources.

Following Ostrom (1990, p. 51), these institutions have to be understood as 'the set of working rules [...] that forbid, permit or require'; and their creation or evolution has to be apprehended as the result of rational choices made by individuals, themselves informed by (i) their discount rate and moral norm, especially regarding the group of which they are a part, and (ii) the potential costs and benefits from a rule change in matters of natural resource management (Ostrom 1990, p. 37). This framework has been particularly useful over the last two decades to discuss several empirical cases and theorizes the conditions under which collective action can lead to sustainable natural resources management.

In the research reported here, the aim is however not to inform about the potentiality for collective action to emerge or maintain, but to shed light on the evolution of interaction patterns between an external actor - the forestry administration, represented by a forest guard - and local communities, and the ecological

\footnotetext{
${ }^{2}$ It is acknowledged that a great diversity exists in the literature devoted to the study of the common property, as noted by Hautdidier (2007).
} 
consequences of these interactions. In such a perspective, there are at least two reasons to mobilize a different framework.

First, it seems important to take better account of the power relationship that link actors together and bring them to negotiate each others behaviour, instead of focusing mainly on the institutions. In this perspective, the power is seen as a component of the relationship and not as a personal attribute; it cannot be separated from the relationship through which it exists (Friedberg 1997 [1993], p. 123). Actors can however benefit from unequally distributed resources, which often leads to asymmetrical relationships (Chazel 1983).

Second, when focusing on local institutional arrangements - as the common property analytical framework leads the researcher to do-the environmental component is often disregarded. What is seen as good forest or natural resources governance (i.e. in accordance with most of the design principles enounced by scholars of the commons) is too easily said to result necessarily in better environmental outcomes. It seems necessary however to keep in mind a clear reference to the quality of the ecosystems involved, if a so-called 'sustainable' management of forest has to be reached. To do so, the definition of ecological indicators is needed; this study relies mainly on an important work of Hammi et al. (2007) which assesses the evolution of tree cover fraction over the last 40 years through diachronic analysis of aerial photography.

To take into account these two critical remarks, a more strategic analytical framework that focuses also on ecological outputs of actors interactions is needed such as the Strategic Environmental Management Analysis (SEMA) framework. This framework allows environmental management situations to be analysed through three different and complementary perspectives - normative, analytic, and strategic-to answer an apparently simple question: how can the environmental management of a particular ecosystem be improved (Mermet et al. 2005; Mermet

2006). This framework has in particular been used to analyse the link between local management and public action in developing countries (Leroy 2006; Leroy et al. 2006; Taravella 2008). In the case of the Ait Bougmez forests, such a framework led to:

- the choice of indicators through which indicators forest quality has to be assessed,

- an understanding of how the various actors involved in forest management had been acting and interacting, and interact today, and of the ecological consequences of these interactions,

- insights into the extent to which a change in the actor configuration-if any change is to occur - can produce significant ecological outcomes, according to the indicator chosen.

This paper focuses particularly on the second and third point and relies on work of Hammi et al. (2007) and Cordier (2007) to discuss the first point. Management of forests by the local population before the forest guard's arrival is derived from previous studies in the Ait Bougmez valley, particularly Lecestre-Rollier (1986, 1992) and Auclair (1991, 1996). 
Comprehensive fieldwork has been conducted for one year in the Ait Bougmez Valley to assess current interaction patterns between the forestry administration and the local population and possible change in actor configuration (both in the forestry administration and in the local organization). Sixty-nine interviews were carried out at the local level, which concentrated on local practices and 'autochthonous' forestry management rule definitions and enforcement, forest guard intervention and forestry law enforcement, as well as emergence of new associations. These interviews followed a semi-structured guide, and comprised:

(i) 40 interviews with smallholders and village leaders;

(ii) nine interviews with the Ait Bougmez forest guard and local managers and engineers of the forestry administration;

(iii) 20 interviews with local NGOs leaders.

At national level, 19 interviews were conducted to understand recent changes in forest policy and the way these changes can be put into practice, particularly in the case of the Ait Bougmez valley. Persons interviewed were all more or less directly involved in forest policies formulation, including high-ranking members of the forestry administration (10 interviews), and national and international experts or professors working as experts for the administration (nine interviews).

\section{The Aït Bougmez Valley Case Study}

The Ait Bouguemez Valley is located in the Central High Atlas in the Azilal province. The valley is about $30 \mathrm{~km}$ long with an altitude ranging from 1,800 to $2,200 \mathrm{~m}$, delimited in the north and south by high mountain ranges reaching 3,700 m (see Fig. 1). Approximately 30 villages are located in the valley, the territories of which are organised perpendicularly to the mountain axis. One can find, from the lower valley upwards, irrigated crops, villages, and some plots of dryland cultivation. The middle and high parts of the slopes are wooded areas. Forest covers about 12,000 ha, and irrigated crops almost 2,000 ha which constitutes one of the largest irrigated area of the whole High Atlas and partially explains the relative richness of the Ait Bougmez valley compared to the rest of the mountain. The other territory is asylvatic spaces at high altitude composed of collective grazing for ovine and caprine flocks. Basically, the agrarian economy of Ait Bougmez relies on the complementarity between various resources (farm crops, irrigation water, pasture land and forests) among which forests plays a major role by providing fodder and firewood during winter, and house-building wood and grazing areas for sheep and goats.

Several changes have occurred during the last two decades, which have profoundly altered the valley by bringing it closer to 'the rest of the world'. Azilal, the closest large town, is a $2.5 \mathrm{~h}$ drive from Marrakech and currently has a population of 27,700 inhabitants. The road from Azilal to the valley was constructed in 2001 and takes a further two hours to negotiate. About two-thirds of the subsequent roads into the valley which provide access to the villages are rough 


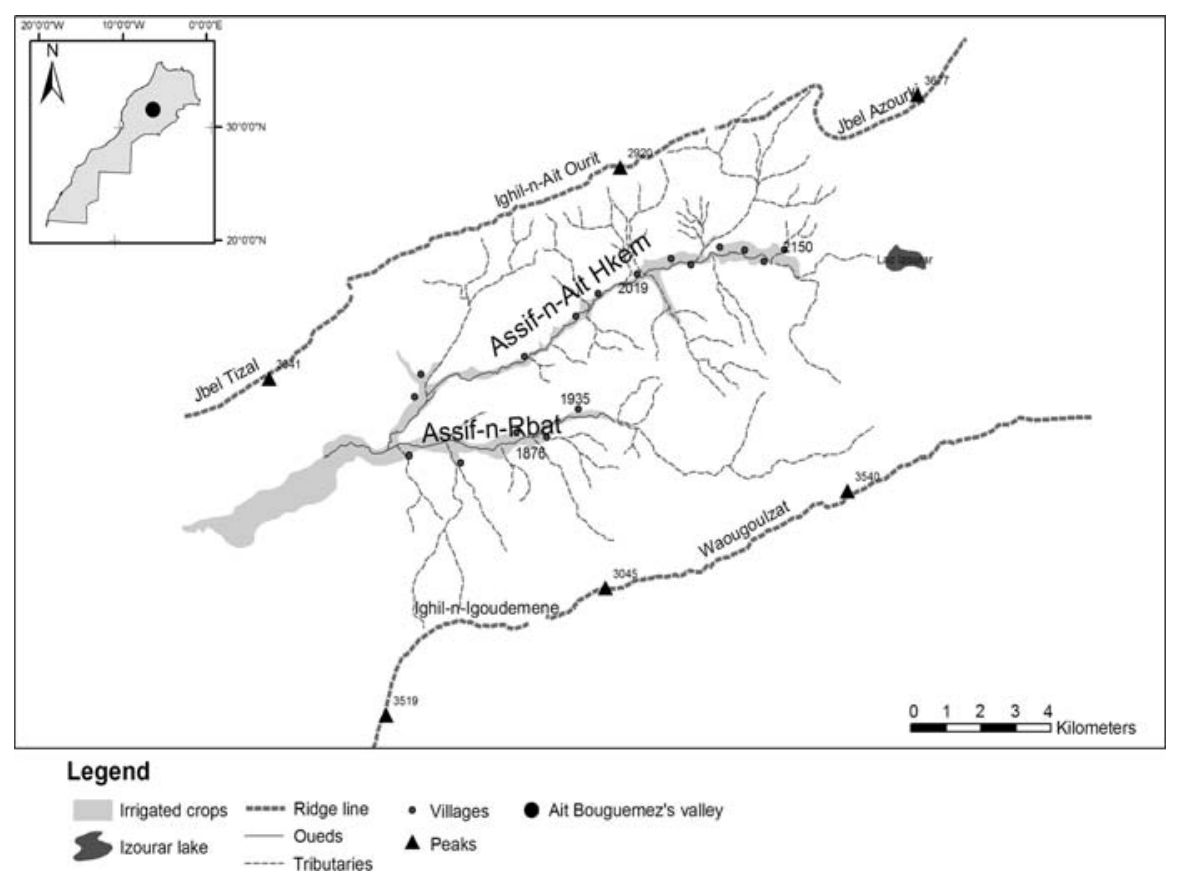

Fig. 1 Location of the Ait Bougmez Valley (reproduced with permission of Sanae Hammi)

tracks. Electricity was brought to all the villages in 2002 and cell phones became operational in 2003.

New economic activities have also appeared in the last 20 years, including the development of commercial agriculture of apples and potatoes and the development of tourism, the latter thanks to a project launched at the beginning of the $80 \mathrm{~s}$ and founded with French cooperation support. These activities were not immediately of interest to people, but they have gained growing attention over recent years. Now, their contribution to the income of most families cannot be neglected, especially in the lower part of the valley. Crucially, the population has almost doubled from 1960 to 2004 , from 6,778 inhabitants to more than 13,000 .

\section{Local Forestry Management Before Arrival of the Forestry Administration}

Theoretically, forestry management in Morocco is governed by the forestry code, which derives from the Dahir relatif à la protection et à l'exploitation des forêts (Law of Forest Protection and Exploitation) issued under French protectorate in 1917. This code presumes each forest stand to be state property and therefore subjected to severe restrictions by the forestry administration.

In Ait Bougmez, the legislation was not enforced until the posting of a permanent forest guard in 1985. As observed by Lecestre-Rollier (1992), who carried out 
extensive research in the valley before this date, forestry management was based on complex property rights and autochthonous regulation.

Village assemblies (called Jmâa in Berber language) define the rules concerning forest resource exploitation, in terms of amount of firewood, fodder and timber that can be cut per family, period of withdrawal and sometimes resource cost (for timber only). One of the most important rules enforced by villagers is the agdal one. The term agdal refers to an area, a resource and the rules laid down to manage this resource-space (Auclair et al. 2006). Agdal forest is forest where cutting branches or trees is strictly forbidden throughout the year except in cases of heavy snowfall or when somebody needs wood to build a house. But grazing of sheep and goats is always allowed. Outside the agdal, other rules exist and are defined by the village assembly. When somebody breaks one of the rules concerning a village forest, they are fined an amount of up to 200 Dirhams, ${ }^{3}$ which has to be paid to the village.

Forest stands further from the villages may also be exploited by several villages (generally no more than two or three). Some rules may exist but not necessarily, depending on the relationships between villages that share the resource.

More generally, forests are all appropriated by the local population and no open access forests exist. The definition and delimitation of village forest territories has however been subject to several conflicts between villages in the late 1970s and early 1980s, as reported by Lecestre-Rollier (1986). Each village now has access to forests, which are from 100 to 200 ha in size, with a few larger forests including that of Ighirine village, in the upper part of the valley.

Forestry management by the local population appears to have been a kind of 'perfect' case study for the scholars of common property. It resembles most of the accepted institutional design principles mentioned above that are considered to be important for sustainable resource management (Ostrom 1990; Romagny et al. 2008). However, from an environmental point of view and according to LecestreRollier (1992), this collective management was insufficient to preserve forest stands, which were already suffering severe depletion. Moreover, this local management was challenged by the forest guard on his arrival in the valley, who had to enforce a forestry law incompatible with local practices.

Two questions must be raised following these statements: 'How was the forestry law enforced in such a context?' and 'Was the forestry administration able to draw upon this 'collective control' over forest stands to improve forest management towards less degradation?'.

Negotiating the Forest Management Rules: Interaction Patterns Between Local Communities and the Forestry Administration

Moroccan forestry law considers all natural forest stands to be state property. There is a total ban on felling of trees for firewood or building, collecting fodder and grazing goats, activities of central importance in the Ait Bougmez economy. Only few land rights are given to users: they are allowed to collect on-the-ground dead 
wood and grazing is limited to the 'family' livestock, i.e. no more animals than the family actually needs to live on, goats excluded. On arrival of the forest guard in 1985, a strict enforcement of the law was thus obviously impossible, especially taking into consideration the forest area he had to control, of more than 12,000 ha. LecestreRollier (1992) observed that his arrival was totally ineffective: people continued to exploit their forest as usual according to their own rules - they just cut wood more discreetly and often during the night. Few fines were imposed although everybody was breaking the law and local people commented casually that 'the forest guard can't do anything'.

Local rules were thus not really changed. But the existence of a double system (local and 'legal') was seen by Lecestre-Rollier (1992) as a breach in the local management system, which could have important consequences. Indeed, 20 years later, the data collected for this study show that several changes have occurred in local forestry management, some of which are directly due to forestry administration intervention:

- Forest areas controlled by villages have decreased because of replanting by the forestry administration. Between 1985 and 2007, more than 2400 ha were replanted across the whole valley (which amounts to about 12,000 ha of forest). After reforestation, an area is considered to definitely belong to the forestry administration whereas other forest stands are generally considered by villagers as their forest. Reforestation areas are often located over stands claimed by two or more villages. Replanting offers an arbitrary solution in areas where previously there may have been an inter-village dispute over the ownership of a particular stand. The stand becomes state forest, and the dispute therefore no longer exists.

- In villages which control a large forest area (and therefore important forest resources), autochthonous rules are not really modified by the forest guard's intervention. However, each time wood is needed (for construction, fodder or firewood), villagers need his 'authorisation' and have to give him a bribe. ${ }^{4}$

- Among these villages, traditional institutions have sometimes lost a part of their local legitimacy in forest exploitation regulation. This is the case for the villages of Aït Imi, Iskattafen and Aguerd'n'Ouzrou. Because forestry management has become by law the forestry administration's task, a growing number of people no longer comply with village rules. Villagers prefer to deal directly with the forest guard, in particular in situations where they know that the amount of wood that they wish to obtain is not likely to be accepted by Jmâa: 'before the forest guard arrived, agdal were well managed in our village. But now, most of people deal directly with him [the forest guard] and they don't care anymore about village rules' (interview with a village leader, village of Aï Imi, 2006).

- Finally, in villages which do not have much forest and which are close to the road (so that it is easy for the forest guard to monitor the forest), forest exploitation has been almost totally forbidden by the guard, who does not accept

\footnotetext{
4 For example, before winter, each village collects between 1000 and 3000 Dirhams and give it to the forest guard to be able to gather firewood during three months (between December and February). Each household has thus to give 50 to 100 Dihams.
} 
any bribes. This concerns essentially villages located in the lower part of the valley (of Timit and Ait Ziri), where this kind of restriction is easier to enforce thanks to major changes in the farming system. The development of tourism and commercial agriculture (apples and potatoes) makes butane gas affordable to a growing number of families, reducing the demand for fuelwood. Also, the decline of pastoralism reduces the need to cut tree leaves during winter for fodder, and as a result of income augmentation families are able to buy cereals (including barley and oats) as an alternative to tree fodder. However, obtaining some firewood to warm the houses during the winter remains necessary even in this part of the valley because fire is the only option to heat houses.

These few examples illustrate how specific negotiations take place in each village, through which both autochthonous rules and the forestry law are redefined. This produces particular and contingent local orders ${ }^{5}$ that link together villagers and the forest guard; their relationship is however marked by an unequal resource distribution which leads to distributive negotiations (Walton and McKersie 1991 [1965]); indeed, the forest guard has the legal authority and benefits from it. In contrast, most villagers need to obtain wood or fodder from the forest and have no alternative than to negotiate from an unfavourable position. But the forestry administration also plays an important role in mediating conflicts between villages through reforestation that is located over stands claimed by two or more villages.

These examples also show that the forest guard takes into account - to some extent- the existing local rules in the negotiation. These rules are indeed not totally ignored or rejected but rather re-defined through specific negotiations. More generally, most forest guards who have worked in the valley as well as the forest engineer responsible for the Ait Bougmez forest know about local rules and especially agdal practices and acknowledge some respect for it: '[Agdal practices] are good things for me. That people want to use the territory in a rational way, it's really good. I consider this as sustainable development' (interview with a forest engineer, May 2006); 'in certain forests of the Province (Ait Bougmez), [...] forest stands are carefully managed under collective control' (forestry administration report about forestry management in Azilal province - MARA 1986, annexe 5.2, p. 10). They however don't recognize it officially which would lead them to loose a strategic advantage to negotiate with local population.

Despite this situation, new national forestry orientations tend toward the idea that recognition of local practices and co-management with local population would be able to improve environmental outcomes of forestry management. Before defining more precisely these 'new' orientations, and following the analytical framework chosen for this case study, one needs to know better the ecological consequences of the evolving forest management system underlined. Some of these consequences include:

- In the upper part of the valley where a diachronic analysis of forest cover evolution between 1964 and 2002 was carried out, 20\% of the previous forest area of 1964 has been totally deforested, which represents a loss of 1,200 ha or

\footnotetext{
5 Crozier and Friedberg (1977) and Friedberg (1997) elaborate the specific notion of 'local order'.
} 
$8 \%$ of forest cover (Hammi et al. 2007). In most villages, forest product withdrawal has increased (except for the few where it has been totally forbidden by the forest guard) and almost all non-agdal forest stands have suffered severe degradation.

- Agdal forest stands have been better protected. Indeed, over the last four decades mean tree cover has increased from $15.8 \%$ to $18.9 \%$, (Hammi et al. 2007). Cordier (2007) showed that forest product withdrawal inside of agdal, for fodder, firewood or timber, is done by local population with a high empirical knowledge of ecological processes that, in most cases, allows forest stands to regenerate and trees to stay alive despite the high degree of exploitation to which they are submitted. Cordier also showed how regeneration depends not only on management rules and practices but also on ecological conditions (including gradient of slopes, soil conditions, exposition and confinement).

- Finally, some areas have been reforested by the forestry administration, which means a relative augmentation of forested area (relative because other parts have been deforested during the same period). About 2,500 ha have been replanted, among which approximately 1,500 have succeeded (though most is at an early stage of growth and cannot yet be called forest stands). Because reforestation has mostly been with exotic species of Cupressus arizonica (almost 70\%), and semi-autochtonous species including Pinus halepensis and Pinus pinaster (which are indigenous in Morocco but not originally in Aït Bougmez Valley) for which regeneration is almost absent at present, the future of these new forest stands is uncertain.

These results take into account three important considerations. First, forest degradation has definitely occurred and is still continuing in the Ait Bougmez Valley, mainly due to the intense exploitation. This degradation is however shaped by local rules and the way they are continuously re-defined through specific negotiations with the forestry administration; it has indeed been shown that agdal forests have been greatly protected whereas non-agdal stands have been almost totally deforested. Finally, the forestry administration intervention has had an impact through the redefinition of 'traditional rules' but that cannot be assessed using diachronic analysis and a tree cover fraction evolution indicator. However, the redefinition of these rules is mainly the consequence of distributive negotiations. These distributive negotiations result themselves - at least partly-from the non-recognition by the forestry administration of local population legitimacy to intervene in forestry management. Will a policy that takes into account the local population as a legitimate interlocutor be able to change the Aiit Bougmez management system and particularly with regard to its environmental outcomes? To answer such a question, it is first necessary to understand more precisely these policy evolutions.

The Evolution of Forest Policy: From Distributive Negotiation to Partnership?

Most officials that were interviewed said the forestry administration has evolved substantially since the mid-1980s, and now attempts to take into account the local 
population's wishes, consider rural poverty before forbidding everything, and seek alternatives to repressive approaches. These ideas are expressed in several strategic plans and programs produced by the administration between 1986 and now. They have been integrated into the National Forest Programme (NFP) adopted in 1999. This program promotes 'a new approach which combines strategic planning, and long term, decentralised and participative processes [which are] necessary to improve the success rate of projects'; furthermore, the new forestry policy has 'to improve livelihood and incomes of rural populations through ... a rational, sustainable, and participatory management of natural resources' (MCEF 1999, p.77).

Two key ideas can summarize the new policy orientations: first, the forestry administration agent has to work as a development agent if he wants forests to be conserved, and second, he has to set up participatory processes to be successful. Both ideas are however not so new in this administration, as Aubert (in press) has shown, and have never been enforced in Aït Bougmez. At least two reasons can explain this lack of enforcement:

- These ideas have never been ratified. Moroccan forest code remains similar to the original dahir of 1917, and its coercive vision of forestry ${ }^{6}$; Moroccan forestry administration agents are therefore asked to manage forest areas through a participatory process without the tools to do so. Moreover, most of them still have in mind the idea, promoted during the time of the French protectorate, that forest appropriation by the state and creation of the forestry administration was necessary to restore the great Moroccan forest depleted by rural populations whose ignorance about natural resources management was total ${ }^{7}$ (Davis 2007).

- As shown in the Aït Bougmez Valley (and reported by several other authors including Fay 1986; Aderdar, 2000 and Aït Hamza et al., 2007), the relationship between the forestry administration and villagers is based on both mistrust and distributive negotiation; this hinders the establishment of a new kind of partnership between them.

In spite of this situation, a ministerial decree proposing compensation for exclusion of grazing animals was issued in 1999, and is presented both as the first step of NFP implementation and as a new tool to put into practice partnerships with the local population (MCEF 2002). The application order for this decree was issued in 2002, but the decree only took effect in 2006 in the Mid Atlas, and the first experience has just been launched in the High Atlas. The decree aims to prevent

\footnotetext{
6 A law about people participation in forest management and economy was issued in 1976, but did not have the intended impact mainly because its application order was never issued and it promoted the rural district as new partners for foresters but totally forgot the tribal communities (MCEF 1999).

7 Boulhol (1952, p. 233) gives a particularly good example of the common discourse about rural population at the time of the protectorate: 'before 1912 [the time French protectorate began in Morocco], anarchy reigned over Morocco .... even if in certain area, rural population seemed to respect common property on forest stand-rather than domanial one-while abusing of it, it was most often that especially in the Berber mountain, the peasant cut the forest to make his field.'.
} 
people from grazing cattle in regeneration stands ${ }^{8}$ by offering them compensation of 250 dirhams per hectare per year, ${ }^{9}$ on condition that they organise themselves into a formal association (under the 1958 law). The monetary compensation is an incentive to respect grazing restrictions and to allow the forest to regenerate.

In concrete terms, the decree application led to the establishment of a contract between the forest administration and the association, of which neither the terms of reference nor the objectives were negotiable. Despite these 'defaults', this decree is currently the only tool available to the forest administration to evolve its relationship with the local population.

How could this decree be applied and how could it change any aspects of local forestry management? This question will be answered by analysing how associations have emerged and what they do today in the valley, focusing on their relationships with both traditional institutions and the forest administration. The associations' capacity to take part in local forestry management through either the implementation of the ministerial decree or the re-formalization of traditional management at the village scale will then be discussed.

\section{Local NGOs and Their Participation in Forest Management}

Since 1998, almost 30 associations have been created in the Aït Bougmez Valley, more than $50 \%$ in the last two years. Looking at their statutes and the projects they have developed up to now, Bougmez' associations mostly work on local and social development through specific actions: literacy training, water reservoir construction, health education, and women development promotion through gender approach. All their activities are financed by external donations, projects such as the National Initiative for Human Development (launched in 2005 by King Mohammed VI) and diverse rural development projects (conducted by the World Bank and a French non-governmental organisation called 'Agronome et Vétérinaire Sans Frontière').

The emergence of local associations is linked with (i) the existence of a development rent created by international development aid and national policies for rural development, from which associations attempt to benefit (as described by Bierschenk et al. 2000), (ii) the increasing desire of the Moroccan state to work closely with local associations, 'in order to concretise the new proximity policy

\footnotetext{
${ }^{8}$ Exclusion of grazing animals has often been presented as the panacea for forest conservation all over Morocco (Davis 2007). Sheep and goats damage forest stands by eating young parts of trees and young trees. Promoting exclusion of grazing animals therefore offers the potential to favour forest regeneration. However, without denying the importance of reducing grazing in forest stands in most cases, other ecological parameters can sometimes better explain forest regeneration. Comparing two stands submitted to the same management practices and pastoral pressure, Cordier (2007, pp. 50-54) found an abundant regeneration in the first one but almost none in the second. The first stand benefited from better ecological conditions due to its location in an area where the humidity and cold air mass accumulate (Rhanem 1985), allowing more rapid regeneration growth.

9 The value of the compensation has been calculated by estimating the average amount of forage that can be yielded from an hectare of forest in Morocco in one year. This amount was calculated to be equivalent to $250 \mathrm{~kg}$ of barley. At the time the application order was issued (2002), $1 \mathrm{~kg}$ of barley was priced at nearly $1 \mathrm{Dh}$; it was therefore decided to fix the compensation value at $250 \mathrm{Dh} / \mathrm{ha} /$ year.
} 
which aims at fighting poverty and improving livelihood' (Royaume du Maroc 2003 , p. 1), and (iii) more generally the growing interest for civil society expressed by international donors and NGOs in Morocco (Mernissi 1997).

The movement started with associations, which wanted to work on a large scale, but recently created associations are mainly village associations, with the scope of their action not going beyond the village scale. Associations now exist in more than 50\% of Ait Bougmez villages. Indeed, the first associations created pretended to work at a multiple-village scale but were said to privilege the village from which they came. People from other villages decided to create their own associations to ensure they gained benefit from interesting projects: 'Other associations have never done anything for our village; that's why we've decided to create our own one' (association leader, Tabant village in Aït Bougmez). And villages have copied each other: 'we saw that other villages developed projects thanks to an association, whereas we didn't have anything. That's why we've decided to create this association' (association leader, Ait Ouham village in Aït Bougmez).

In such a context, the implementation of the ministerial decree on compensation of exclusion of grazing animals - which relies on the existence of local associa- tion-could be thought to be relatively easy. At the end of 2006, the forestry administration district of Azilal expressed the wish to put it into practice (interview with a forest engineer in Azilal, May 2006). However, during the last two years, the administration has not contacted any local association in the valley but rather has attempted to implement the ministerial decree by creating a new association especially dedicated to this purpose, in the village of Ighirine-Iglouane. Moreover, the forest engineer in charge of the Ait Bougmez forest, located around $80 \mathrm{~km}$ from the valley, had never heard about local associations before launching this experiment. Despite its claims, the forestry administration (at least the service of the Azilal province, where the Ait Bougmez Valley is located) seems thus to keep quite a vertical approach of forest management. As a consequence, none of the associations mentioned above has been in contact with the forestry administration until now and they even ignore the existence of the decree about compensation for exclusion of grazing animals.

Focusing on the current experiment in the village of Ighirine-Iglouane, some key conclusions can be derived. First, discussions have only been conduced between the president of the newly created association and the Azilal forest engineer. The president is a young teacher from the village who is especially engaged in local NGO emergence. He is typically what Olivier de Sardan (2005, p. 174) calls a 'broker': a social actor involved in a local arena that tries to play the role of intermediate between two 'worlds' in order to reinforce his own position in the local arena. If new negotiation opportunities can emerge from this process, they do not therefore involve actors previously implicated in forestry management, namely the forest guard of the Ait Bougmez Valley and 'normal' villagers. It thus seems doubtful that this experiment could lead to effective changes in the forestry management system. But this statement can be extended to all the associations newly created in Ait Bougmez. None of them has been able until now to take any 
action in the field of forest resources management, and more generally natural resources management. ${ }^{10}$ At least two reasons can be advanced to explain it:

- 'Traditional' institutions are still in charge of collective pastureland and irrigation system management. ${ }^{11}$ Management of the various natural resources is linked because of their complementarity in local farming systems, so it would seem inconsistent to have one resource managed by the association and others by traditional assemblies.

- The local authority (the Caid) wishes to preserve the existence of the Naib, a person chosen by Jmâa to monitor if its decisions are well enforced. The Caid does not consider an association to be the equivalent to the Jmâa, because it does not express general interest as the Jmâa does: 'Is the association in a position to work as the Jmâa does? It is not. This is because of the existence of customary rights, over which the association doesn't have any control' (caïd of Ait Bougmez). He tries to influence villages in favour of maintaining traditional rules.

The context is thus characterized by the low legitimacy of local NGOs, which prevents them from taking any action concerning natural resource management. In such a context, the ministerial decree which relies on these NGOs to be put into practice is not likely to produce any effective change in local forestry management systems. Local NGOs might need to gain more legitimacy to be able to intervene, take part and modify current negotiations through which forestry management rules are set up and put into practice.

\section{Conclusion}

In conclusion, the main intent of this paper is to show the results produced by a theoretical change of viewpoint from that of the new institutionalist approach to that of the SEMA framework. Using this framework, the paper explores the historical evolution and the ecological consequences of interaction patterns between local populations in the Ait Bougmez Valley and other actors, particularly from the forestry administration. It demonstrates that current forestry management results from negotiations between local populations and the forest guard who arrived in the valley in 1985. Both the forest legislation and the historical, traditional system of regulation are re-defined permanently as a result of these negotiations. The traditional system of regulation, in which the agdal rule plays an essential role, has thus not been completely abandoned, or outlawed by the forestry administration. It

\footnotetext{
10 Two local NGOs (in the villages of Ait Ouham and R'Bat) have expressed the wish to deal with forest management; the first tried to prevent villagers from cutting wood and to convince them of the benefits of replanting, and the other attempted to change rules concerning evergreen oak exploitation, but both were unsuccessful.

11 Legal associations have been created to manage irrigation systems, as a condition of their improvement being financed by the World Bank. However, up to the present they have never been able to take part in decisions concerning day-to-day water management, which remains the village assembly's responsibility (Riaux 2006).
} 
even continues to affect forests ecological condition and its evolution. Negotiations with the forestry administration have also produced environmental outcomes which cannot be ignored, in particular the reforestation of contested areas. However, substantial demographic pressure combined with the absence of economic alternatives to sylvopastoral production has led to severe forest depletion. Almost $20 \%$ of the 1964 forest surface area has been completely deforested.

The implementation of a new forest policy tool which aims at setting up contractual management between the forestry administration and these local populations has to be understood as an attempt to transform the local order. Such contractual management seeks to improve both the ecological outcomes of forest management and relationships between the local population and the forestry administration. It relies on the formalisation of local NGOs as the new interlocutors for the forestry administration. Up to now, however, these NGOs have not had access to negotiations defining forestry management rules. The impact of this new policy tool will remain limited as long as this situation lasts. As much as it took time for the forest guard arrival to provoke an effect on the local system, one can assume that it will take time for new negotiation opportunities which could lead to the definition of new local orders with different ecological outcomes.

Such a diachronic and strategic analysis which takes more account of environmental consequences of actor inter-relationships is only possible because of the shift in theoretical and analytical approach adopted by this paper. A more standard new institutional framework would have led to a focus mainly on traditional forest management and the disturbances provoked in it by the forest administration, instead of examining their interactions and their consequences.

\section{References}

Aderdar M (2000) Espace forestier et aménagement des zones de montagne: le cas du Haut Atlas de Marrakech. Thèse de Doctorat en Géographie, Grenoble, Université Joseph Fourier, Grenoble

Agrawal A (2001) Common propery institutions and sustainable governance of resources. World Dev 29(10):1649-1672. doi:10.1016/S0305-750X(01)00063-8

Ait Hamza M, Auclair L, Benchekroun F, Genin D, Qarro M, Romagny B, Zagdouni L (2007) De la parole aux gestes. Éléments de réflexion sur les dispositifs de gestion concertée des ressources forestières et pastorales au Maroc. IRD - ENFI - SCAC de l'Amabassade de France, Rabat

Aubert PM (in press) Reconnaissance des pratiques locales et participation: l'administration forestière face à l'agdal. In: Auclair L (ed) Les agdals du Haut Atlas marocain: biodiversité et gestion communautaire des ressources sylvopastorales. Marrakech

Auclair L (1991) Bois de feu et sociétés rurales. Haut-Atlas et région présaharienne (Maroc). Comportements énergétiques et modes de gestion des ressources naturelles. Thèse de Docteur Ingénieur en Agro-économie, École Nationale Supérieure Agronomique de Montpellier, Montpellier

Auclair L (1996) L'appropriation communautaire des forêts dans le Haut Atlas marocain. Cah Sci Hum 32(1):177-194

Auclair L (1998) Les ressources sylvopastorales au Maghreb. Structure segmentaire et appropriation communautaire. In: Rossi G (dir.). Sociétés rurales et environnement. Karthala/GRET, Paris

Auclair L, Bourbouze A, Dominguez P, Genin D (2006) Les agdals du Haut Atlas (Maroc): Biodiversité et gestion communautaire de l'accès aux ressources forestières et pastorales. Rapport de recherche, IFB - IRD - UCAM, Paris-Marseille-Marrakech

Baland JM, Platteau JP (1996) Halting degradation of natural resources: is there a role for rural communities? Clarendon Press, Oxford 
Behera B, Engel S (2006) Institutional analysis of evolution of joint forest management in India: a new institutional economics approach. For Policy Econ 8(4):350-362. doi:10.1016/j.forpol.2005.08.006

Bierschenk T, Chauveau JP, Olivier de Sardan JP (eds) (2000) Courtiers en développement. Les villages africains en quête de projet, Khartala et APAD, Paris

Boulhol P (1952) Législation forestière marocaine. Rev Forestiere Fr 1(4):232-245

Chazel F (1983) Pouvoir, structure et domination. Rev Fr Sociol 24(3):369-393. doi:10.2307/3321866

Cordier JB (2007) Impact écologique des pratiques d'agdal sur les peuplements forestiers et proposition de gestion alternative - Vallée des Ait Bougmez, Haut Atlas Central, Maroc. Mémoire de fin d'étude pour l'obtention du diplôme d'Ingénieur Forestier, ENGREF - IRD LPED, Montpellier - Marseille

Crozier M, Friedberg E (1977) L'acteur et le système. Seuil, Paris

Davis DK (2007) Resurecting the granary of Rome - environmental history and French colonial expansion in north Africa. Ohio University Press, Athens

Fay G (1986) Ré-inventer la jma'a: réflexions pour le développement des milieux pastoraux. Bull Econ Soc Maroc 161:113-125

Friedberg E (1997) Le pouvoir et la Règle. Dynamique de l'action organisée. Seuil, Paris

Hammi S, Simonneaux V, Alifriqui M, Auclair L, Montès N (2007) Évolution des recouvrements forestiers et de l'occupation des sols entre 1964 et 2002 dans la haute vallée des Ait Bouguemez (Haut Atlas central, Maroc). Secheresse 18(4):271-277

Hardin G (1968) The tragedy of the commons. Science 162(3859):1243-1248

Hautdidier B (2007) Bûcherons et dynamiques institutionnelles locales au mali - La gouvernance incertaine des ressources ligneuses des environs de Bamako, a travers l'étude des marches ruraux de bois de la commune de Zan Coulibaly. Thèse de Doctorat en Sciences de l'Environnement, AgroParisTech-ENGREF, Montpellier

Johnson C (2004) Uncommon ground: the 'Poverty of History' in common property discourse. Dev Change 35(3):407-433. doi:10.1111/j.1467-7660.2004.00359.x

Lecestre-Rollier B (1986) L'espace collectif et les conflits chez les Ait Bou Guemez du Haut Atlas Central (Maroc). Technol Cult 7:95-111

Lecestre-Rollier B (1992) Anthropologie d'un espace montagnard. Les Ayt Bou Guemez du Haut Atlas marocain. Thèse de Doctorat en Anthropologie. Université René Descartes - Paris V, Paris

Leroy M (2006) Gestion stratégique des écosystèmes du fleuve Sénégal: action et inaction publiques internationales. L'Harmattan, Paris

Leroy M, Mathieu G, Méline V, Moulin CH (2006) La gestion communautaire des ressources comme principe de gestion environnementale en Namibie (Nord-Central): évaluer les dispositifs pour éviter les mots d'ordre. In: Auclair L, Aspe C, Baudot P (eds) Le retour des paysans? À l'heure du développement durable. IRD/SEH, Marseille, pp 275-298

MARA (1986) Aménagement et Développement des Zones de Montagne du Haut Atlas Central - Rapport Intérimaire - Tome IV - Annexe 5: Reconstitution et développement des forêts. Ministère de l'Agriculture et de la Réforme Agraire - Direction des Eaux et Forêts et de la Conservation des Sols, Azilal

MCEF (1999) Programme Forestier National - Rapport final. Ministère chargé des Eaux et Forêts, Rabat

MCEF (2002) Circulaire relative à l'application de l'arrêté sur la Compensation des mises en défens. Ministère Chargé des Eaux et Forêts - Direction du Développement Forestier, Rabat

Mermet L (2006) [1998] L'analyse Stratégique de la Gestion Environnementale. Illustrée par les tribulations d'un noyau relictuel de population d'Ours brun dans les Pyrénées Occidentales françaises. AgroParisTech-ENGREF, Paris

Mermet L, Billé R, Leroy M, Narcy JB, Poux X (2005) L'Analyse Stratégique de la Gestion Environnementale: un cadre théorique pour penser l'efficacité en matière d'environnement. Nat Sci Soc 13:137-147. doi:10.1051/nss:2005018

Mernissi F (1997) ONG rurales du Haut-Atlas - Les Aït-Débrouille. Marsam, Rabat

Olivier de Sardan JP (2005) Anthropology and development. Understanding contemporary social change. Zed Books, London

Ostrom E (1990) Governing the commons-The evolution of institution for collective action. Cambridge University Press, New York

Rhanem M (1985) Étude phyto-écologique des versants de la vallée des Aït Bou Guemmez (Haut Atlas Central Septentrional, Maroc). Thèse de Doctorat en Écologie, Université des Sciences et des Techniques du Languedoc, Montpellier

Riaux J (2006) Règles de l'état-règles de la communauté: une gouvernance locale de l'eau. Thèse de Doctorat en Anthropologie sociale, EHESS, Paris 
Romagny B, Auclair L, Elgueroua A (2008) La gestion des ressources naturelles dans la vallée des Ait Bouguemez (Haut Atlas): la montagne marocaine à la recherche d'innovations institutionnelles. Mondes Dev 36(1):63-80. doi:10.3917/med.141.0063

Royaume du Maroc (2003) Circulaire no 7/2003 relative au partenariat entre l'État et les Associations. Cabinet du Premier Ministre, Rabat

Schanz H (2002) National forest programmes as discursive institutions. For Policy Econ 4:269-279. doi: 10.1016/S1389-9341(02)00077-1

Taravella R (2008) La frontière pionnière amazonienne aujourd'hui: Projet socio-environnemental de conservation forestière contre dynamique pastorale de déforestation - Une analyse stratégique 20002006 de l'action collective en «Terra do Meio » (Pará, Brésil). Thèse de Doctorat en Sciences de l'Environnement, AgroParisTech-ENGREF, Paris

Walton RE, McKersie RB (1991) [1965] A behavioral theory of labour negotiations: an analysis of a social interaction system. Cornell University Press, Ithaca 